\section{Piotr Goniszewski}

Uniwersytet Szczeciński

piotr.goniszewski@usz.edu.pl

ORCID: 0000-0002-1090-9846

DOI: http://dx.doi.org/10.12775/BPTh.2019.014
Biblica

et

Patristica

Thoruniensia

12 (2019) 3: 255-270

ISSN (print) $1689-5150$

ISSN (online) 2450-7059

\title{
Quotations from the Scriptures and from the Works of the Church Fathers in Sermon-Conferences of St. Thomas Aquinas on the Apostles' Creed (Prooemium and Articles 1-3)
}

\author{
Cytaty z Pisma Świętego i Ojców Kościoła \\ w wykładzie Składu apostolskiego \\ św. Tomasza z Akwinu (prooemium i artykuły 1-3)
}

\begin{abstract}
The aim of the article is to analyze the quotations from the Holy Scriptures and the Fathers of the Church featured in the sermons of St. Thomas Aquinas on the theme of the Apostolic Symbol (Prooemium and Articles 1-3). The article provides an inventory of quotations, indicating their number and the use of individual books of the Bible, as well as the works of patristic authors. Furthermore, their type and function in the Prooemium and in the lecture of the first three parts of Symbolum Apostolorum have been shown. When examining the quotations taken from the Holy Scriptures and the works of the Holy Fathers of the Church, we use the elements of an intertextual texture approach, or more precisely the oral-scribal intertexture, whereby both methodologies originate from the socio-rhetorical method coined by V.K. Robbins.
\end{abstract}

Streszczenie. Celem artykułu jest analiza cytatów z Pisma Świętego i Ojców Kościoła w kazaniach Tomasza z Akwinu na temat Symbolu apostolskiego (prooemium i artykuły 1-3). W artykule zostaje przeprowadzona inwentaryzacja cytatów, wskazująca ich ilość oraz wykorzystanie poszczególnych ksiąg Biblii i autorów patrystycznych. Ponadto, ukazano ich rodzaj oraz funkcję w prooemium oraz w wykładzie pierwszych trzech części Symbolum apostolorum. Badając cytaty zaczerpnięte z Pisma Świętego oraz Ojców Kościoła korzystamy z elementów podejścia intertekstualnego (intertextual texture), a dokładniej oral-scribal intertexture, z metody socjoretorycznej V.K. Robbinsa.

Keywords: Thomas Aquinas; biblical Thomism; Church Fathers; Apostles' Creed.

Słowa kluczowe: Tomasz z Akwinu; biblijny tomizm; Ojcowie Kościoła; Symbol apostolski. 
Tn the history of the Christian thought, Thomas Aquinas is known primarily as a philosopher and a theologian, famously transplanting the output of Aristotle onto the Western world. At present, we are also observing an increased interest in the exegetical research conducted by Aquinas over the Bible and its reception, as well as in his creative use of the heritage of the Church Fathers.

In this article, we wish to focus on a different area of the works by Aquinas. We ought to bear in mind that this particular thinker was not only an eminent academician, theologian and philosopher, but - above all - a monk, a cleric, a spiritual person, and a member of the Dominican Order. This is an extremely important fact that not only impacts the evaluation, but also the interpretation of his strictly scientific work. Neither did Thomas Aquinas shy away from the broadly-conceived pastoral activity, which is manifested in his sermons addressed to ordinary believers. These works are extremely intriguing, as they let us see how scholastic theology and philosophy can be implemented for pastoral purposes. We note therein the outstanding skill of Aquinas to synthetically and simply capture the often intricate and complex theological issues, such as his trinitarian theology, for example.

Taking the sermons of Thomas Aquinas on the Apostolic Symbol (Prooemium and articles 1-3) as the subject of our analysis, we will focus on the quotations from the Holy Scriptures and the works of the Church Fathers contained therein. Considering the length limit of the paper we will only consider these four points. First of all, we will make an inventory of these quotations, indicating their number and the use of individual books of the Bible and that of the works of patristic authors. Furthermore, we will try to show their type and function in the Prooemium and in the lecture of the first three parts of the Symbolum apostolorum.

When examining the quotations taken from the Holy Scriptures and the works of the Church Fathers, we will be implementing the elements of an intertextual approach (intertextual texture), or more precisely, the oral-scribal intertexture, whereby both terms were coined by V.K. Robbins ${ }^{1}$ as part of his socio-rhetorical method.

Our focus here is on his understanding of the quotations, referred to as recitations. V. K. Robbins introduces a highly detailed classification of recitations, starting from verbatim forms based on the source text, and ending with very "liberal" references to the materials used.

1 For more on the socio-rhetorical approach, cf.: V.K. Robbins, Tapestry of Early Christian Discourse. Rethoric, Society, and Ideology; idem, Exploring the Texture of Texts: A Guide to Socio-Rhetorical Interpretation; idem, The Invention of Christian Discourse; M. Kowalski, Retoryka i socjoretoryka, pp. 107-147. 


\section{A Historical and Critical Introduction to the Sermons on Symbolum Apostolorum}

Before we proceed with the analysis of the quotations from the Scriptures and from the works of the Church Fathers, let us first place the sermons by Aquinas pertaining to the Apostolic Symbol within the historical context of his life and work. ${ }^{2}$ Very often, the sermons in which we vest our interest are dated for the Lenten period of 1273 - about one year before the writer's death. As emphasized by J. Salij, this was a particularly prolific period of Aquinas' creation, lasting until December 6, when he partook in an extremely intriguing mystical experience, after which he ceased all of his theological output:

The situation at the university allowed him to direct his efforts to his work on the Summa Theologiae. He then devised the Christological treatise of Summa (which he barely started in Paris) and the treatises on the sacraments of Christian initiation, especially the particularly valuable treatise on the Eucharist. At that time, Thomas also wrote the Summa Theologiae, as well as his article On Pure Substances, both of which are of high significance in his theological output. In addition, he worked intensively - all this happened in the same year of 1273 ! - on a few commentaries on Aristotle. ${ }^{3}$

If such a dating is true, we can see that the homiletic lecture of the Symbolum Apostolorum pertains to a period when the theological thought of the Angelic Doctor was already very mature and deepened. Undoubtedly, this fact enabled him to make pastoral syntheses and summaries presenting - in a relatively accessible form - the complex problems of the Christian doctrine. Naturally, other scholars do come up with more moderate opinions, such as that of P. Mandonnet regarding the dating of these collations. ${ }^{4}$

J.-P. Torrell also does not exclude the doubt as to the sermon on the Apostles' Creed in $1273 .^{5}$

In its present form, the sermon on the Symbolum Apostolorum has the character of a reportata, in other words: a record made by Reginald of Piperno,

2 In this article, we will be using the Polish translation of the sermon contained in the following collection: Tomasz z Akwinu, Wykład Pacierza; we will also be using the Latin wording of reportatio taken from: Thomas Aquinas, Expositio in Symbolum Apostolorum. Reportatio Reginaldi de Piperno, http://www.corpusthomisticum.org/csv.html [accessed on 04.04.2019].

3 J. Salij, Słowo wstępne, in: Tomasz z Akwinu, Wykład pacierza, p. 6.

4 P. Mandonnet, Le Carême de saint Thomas d'Aquin à Naples, pp. 195-212.

5 J.-P. Torrel, Saint Thomas of Aquinas, p. 443. 
a student of Aquinas. This is important insofar as Thomas Aquinas preached these sermons in the Neapolitan dialect of the Italian language and not in Latin. Since Reginald of Piperno is considered to be highly versed in theology and the way of thinking practiced by the Angelic Doctor, we can assume that the Latin text of collationes faithfully reflects not only the spirit but also the letter of these sermons.

Now, regarding the literary style of Thomas the preacher, let us quote the words of J.-P. Torrell, who very suggestively characterized the style of a master from Naples:

In contrast to many of his contemporaries, Thomas stands out with his simplicity and restraint, as well as a lack of scholastic complexities and technical terms. This intentional reticence does not exclude scientific vocabulary exclusively; he also rejects oratorical pomposities. If Thomas acknowledges that orators need art that arouses certain emotions, then he refuses to reduce this art to the wisdom of the world. That is why he hardly uses such stories (exempla), which were highly valued by many other preachers. On the contrary, he warns against what he refers to as "trifles" (frivolitates). ${ }^{6}$

Thus, we can see that, as in the case of his purely scientific output, similarly in the case of collationes, Aquinas prefers a clear, logical discourse, free from an excessive number of metaphors and images that could obscure the comprehensibility and the inherent meaning of the argument. A special place in his sermons is occupied by quotations from the Holy Scriptures and references to the Fathers of the Church. It is those very quotations which serve to show us the thoughts of the Angelic Doctor on the subject and how his lectures spring from the living Tradition of the Church.

\subsection{Introduction (Prooemium)}

The table below is divided into two columns. The first one presents quotations from the Holy Scriptures in the order of appearance in the text of the Apostles' Creed. The second one, in turn, contains the quotations and references to the works of the Fathers of the Church.

\footnotetext{
6 J.-P. Torrel, Saint Thomas of Aquinas, p. 98.
} 


\begin{tabular}{|l|l|}
\hline \multicolumn{1}{|c|}{ The Scripture } & \multicolumn{1}{|c|}{ The Church Fathers } \\
\hline His 2:22 & St. Augustine (p.1) \\
Mk 16:16 & \\
Heb 11:6 & \\
Rom 14:24 & \\
J 17:3 & \\
Heb 11:1 & \\
J 20:29 & \\
Hab 2:4 & \\
Isa 11:9 & \\
Heb 11:33 & \\
1P 5:8-9 & \\
1 J 5:4 & \\
Eph 6:16 & \\
Job 36:26 & \\
Sir 3:23 & \\
1Tm 6:4 & \\
2Tm 1:12 & \\
Sir 2:8 & \\
\hline
\end{tabular}

This is the distribution of the individual quotations as per the canonical system:

OT:

Historical Books: -

Wisdom Books: Job 32:36; Sir 2:8; Sir 3:23;

Prophetic Books: Isa 11:9; Hos 2:22; Hab 2:4;

NT:

Narrative Scriptures (Mt, Mk, Lk, J, Acts): Mk 16:16; J 17:3; J 20:29;

Corpus Paulinum: Rom. 14:24; Eph 6:16; 1 Tm 6:4; 2 Tm 2:12; Heb 11:1; Heb 11:6; Heb 11:33;

Catholic Epistles: 1P 5:8-9; 1 J 5:4;

Apocalypse: -

The content of the Prooemium to the sermon on the Symbolum Apostolorum focuses on the central meaning of the theological virtues of faith in the life of a Christian (Primum quod est necessarium Christiano, est fides, sine qua nullus dicitur fidelis Christianus). This collatio features 18 quotations from the Holy Scriptures, six of which originate from the Old Testament, while the remaining 12 were taken from the books of the New Covenant. Aquinas most often draws from the Corpus Paulinum, using as many as 7 texts. Essentially, these 
are classic quotations that in the light of the V.K. Robbins' typology (oral-srcibal intertexture) are referred to as a replication of the exact words of another written text or a replication of exact words with one or more differences. In referring to specific passages of the Bible, Thomas Aquinas uses the Latin text of the Vulgate, but in view of the framework of this article, we will not venture into the field of literary critique and we will not deliberate on the versions of the Scriptures functioning in medieval christianitas. We must remember that Aquinas used, among others, the so-called Paris Bible and in the case of psalms different versions of this book. Let us consider as few as three sample quotations to see that - indeed - we are mostly dealing with nearly literal or only slightly modified intertextual relations with particular fragments of the Scriptures.

\begin{tabular}{|c|c|}
\hline Hos 2:22 & Collationes in Symbolum Apostolorum \\
\hline sponsabo te mihi in fide & sponsabo te mihi in fide \\
\hline \multicolumn{2}{|l|}{ Mk 16:16 } \\
\hline $\begin{array}{l}\text { qui crediderit et baptizatus fuerit salvus } \\
\text { erit }\end{array}$ & $\begin{array}{l}\text { qui crediderit et baptizatus fuerit, salvus } \\
\text { erit }\end{array}$ \\
\hline \multicolumn{2}{|l|}{ Heb 11:6 } \\
\hline $\begin{array}{l}\text { sine fide autem inpossibile placer (Biblia } \\
\text { Sacra Iuxta Vulgatam Versionem) } \\
\text { sine fide autem impossibile est placere } \\
\text { Deo (Vulgata Clementina) }\end{array}$ & $\begin{array}{l}\text { sine fide autem impossibile est placere } \\
\text { Deo }\end{array}$ \\
\hline
\end{tabular}

Out of the 18 quotations from the Bible, there is only one reference to the works of the Fathers of the Church. Aquinas quotes the commentary of St. Augustine regarding Rom. 14:23: ubi non esta eternae et incommutabilis veritatis agnitio, falsa est virtus etiam in optimis moribus. This proportion - in the context of which biblical quotations are prevalent, and whereby the references to the Fathers are merely occasional - will be preserved in all sermons devoted to the Apostles' Creed. Why is there such a disproportion and what is the reason behind it? We must remember that the public of the Angelic Doctor comprised of highly divergent listeners. Naturally, it would also happen that there were some educated members among them, oftentimes his confreres from the Dominican Order, but we can assume that most of his listeners were illiterate. Therefore, they were not people who had access to both the biblical books and the patristic writings. In view of the fact that the Holy Bible as an inspired and canonical text had the paramount auctoritas, most people became familiar 
with it during the liturgy. The knowledge of the Church Fathers was undoubtedly much more limited and only individual figures were often considered as saints. An example may be St. Augustine mentioned in the Prooemium, who constituted the most important patristic auctoritas for the scholastic theology. ${ }^{7}$ Self-evidently, an ordinary believer was not familiar with the writings and complexities of the Augustinian doctrine, but he would have known St. Augustine as a miraculously converted great thinker of the Church. Hence, we can say that the social function of the Holy Scriptures as the basic auctoritas was decisive for the priority of biblical quotations as forming part of the seromon on the Apostolic Symbol. The introduction of further references to the Bible was intended to show the biblical context of the Christian profession of faith. Naturally, many listeners of Aquinas possibly did not even know the contents and titles of individual books that make up the canon of the Holy Bible. However, the manner in which the sermon was delivered, wherein these quotations from the Bible were clearly signaled, had a very important rhetorical function. The recipients, upon hearing quotations from the Scriptures again and again, would realize that their faith is embedded within the space of the Word of God.

Similarly, in the case of the great theological syntheses and other speculative works, the quote from the Holy Bible is not merely an ornament of a rational disquisition. In evoking only a fragment of the Scripture, Aquinas referred to the theological and literary context of the given pericope.

The fragments quoted with high frequency were the subject of more rigorous and detailed studies in the other works of the Angelic Doctor - especially the exegetical ones. ${ }^{8}$ Hence, in his subsequent reflections, he was able to refer his listeners to a more in-depth understanding of the text invoked, by quoting only a fragment. Again, we must point out that these nuances would have been completely incomprehensible to a large part of the public. They did not have the opportunity to familiarize themselves with the exegetical works of Thomas Aquinas or with those written by other scholastic theologians. However, the scientific reliability of Aquinas assumed that by quoting a passage from the Scripture, he made a reference to its broader theological and literary context.

7 On the function of auctoritates in medieval scholastics, cf.: M.-D. Chenu, Wstęp do filozofii św. Tomasza $z$ Akwinu, pp. 120-133.

8 For more on the role of the Holy Bible in the thought of Aquinas, cf.: M.-D. Chenu, Introduction to the Philosophy of St. Thomas Aquinas, pp. 224-252; W.G.B.M. Valkenberg, Words of the living God:; M. Levering, Holy Scripture and Metaphysics; M. Dauphinais, M. Levering (eds.), Reading John with St. Thomas Aquinas; M. Levering, M. Dauphinais (eds.), Reading Romans with St. Thomas Aquinas; P. Roszak, J. Vijgen (eds.), Reading Sacred Scripture with Thomas Aquinas; P. Roszak, J. Vijgen (eds.), Towards a Biblical Thomism. On the function of biblical citation in Thomas Aquinas' interpretation of the Scripture see above all: P. Roszak, The place and function of biblical citation in Thomas Aquinas' exegesis, in: P. Roszak, J. Vijgen (eds.), Towards a Biblical Thomism, pp. 115-139. 


\subsection{Article No. 1 (Credo in unum Deum patrem omnipotentem, creatorem caeli et terrae)}

Firstly, I wish to present a table featuring quotations from the Holy Scriptures and the writings of the Church Fathers in a lecture on the first article of Symbolum Apostolorum.

\begin{tabular}{|l|l|}
\hline \multicolumn{1}{|c|}{ The Scripture } & The Church Fathers \\
\hline Ps 14[13]:1 & St. Augustine (1.20) \\
Job 22:13-14 & \\
Job 11:5-6 & \\
Ps 64[63]:7-9.11 & \\
Heb 4:13 & \\
Wis 13:2 & \\
Isa 51:6 & \\
Jud 6:2 & \\
Wis 14:21 & \\
Isa 14:13-14 & \\
Mt 4:9 & \\
Ps 96[95]:5 & \\
1Cor 10:20 & \\
Jer 10:2-3 & \\
Acts 5:29 & \\
Phil 3:19 & \\
Wis 13:1-4 & \\
Gen 1:1 & \\
J 1:3 & \\
2P 3:4 & \\
Ps 148:5 & \\
Wis12:18 & \\
Wis 13:3-4 & \\
Job 36:26 & \\
1Cor 4:7 & \\
Ps 24[23]:1 & \\
Ps 116[114-115]:12 & \\
Job 2:10 & \\
Prov 16:4 & \\
Dt 4:19 & \\
1Crn 29:14 & \\
Ps 8:7 & \\
Gen 1:26 & \\
\hline
\end{tabular}


The distribution of the quotations in the canonical system of the Holy Bible:

OT:

Historical Books: Gen 1:1; Gen 1:26; Dt 4:19; 1Crn 29:14; Jud 6:2;

Wisdom Books: Job 2:10; Job 22:13-14; Job 22:13-14; Job 36:26; Ps 8:7; Ps 14 [13]:1; Ps 24 [23]:1; Ps 64 [63]:7-9.11; Ps 96 [95]:5; Ps 116 [113-115]:12; Ps 148:5; Prov 16:4; Wis 12:18; Wis 13:1-4; Wis 13:2; Wis 13:3-4; Wis 14:21;

Prophetic Books: Isa 14:13-14; Isa 51:6; Jer 10:2-3;

NT:

Narrative Scriptures (Mt, Mk, Lk, J, Acts): Mt 4:9; J 1:3; Acts 5:29;

Corpus Paulinum: 1Cor 4:7; 1Cor 10:20; Phil 3:19; Heb 4:13;

Catholic Epistles: 2P 3:4;

Apocalypse: -

Commenting on the first article of the Apostolic Symbol (Credo in unum Deum patrem omnipotentem, creatorem caeli et terrae), which is devoted to the issues of the existence and uniqueness of God (De Deo uno) and those of the creation of the world, Aquinas quotes various fragments of the Holy Scriptures 33 times. As many as 25 times these are paragraphs taken from the Old Testament, out of which 17 come from a collection of wisdom books. Quotations from the New Testament appear only 8 times. Such a choice of the biblical sources on the part of the Angelic Doctor should not come to us as a surprise. If the subject of his article on the Symbolum Apostolorum was the faith in the one true God and the creator of the world, then it would seem only natural that Thomas Aquinas would reach for those parts of the Old Testament in which the relationship between Israeli monotheism and cosmology and cosmogenesis is particularly emphasized.

In this part of Symbolum Apostolorum, Aquinas refers to the Fathers of the Church only once. This is yet another reference to St. Augustine (Contra hos ponit Augustinus tale exemplum). In this case, however, we are not dealing with the literal invocation of the source, but only with a highly liberal intertextual relationship. Applying the reclassification criteria developed by V.K. Robbins, we can say that Aquinas is summarizing his source, i.e. it is most likely a recitation that summarizes a span of text. Regrettably, Aquinas does not state the source from which he obtained this thought of St. Augustine. 


\subsection{Article No. 2 (Et in Iesum Christum, filium eius unicum, dominum nostrum)}

Below we present a table containing quotations from the Holy Scriptures and from the writings of the Church Fathers, as featured in a lecture on the second article of Symbolum Apostolorum:

\begin{tabular}{|l|l|}
\hline \multicolumn{1}{|c|}{ The Scripture } & \multicolumn{1}{|c|}{ The Church Fathers } \\
\hline 2P 1:16-18 & Fathers (2.29) \\
J 1:18 & Fathers (2.30) \\
J 8:58 & Fathers (2.31) \\
J 8:16 & \\
J 10:30 & \\
J 1:1 & \\
J 1:3 & \\
Eph 3:17 & \\
J 5:38 & \\
Ps $119[118]: 11$ & \\
Ps $1: 2$ & \\
Lk 2:51 & \\
Eph 4:29 & \\
Col 3:16 & \\
2Tm $4: 2$ & \\
Jam $1: 22$ & \\
Lk $1: 35$ & \\
Lk 1:38 & \\
\hline
\end{tabular}

The distribution of quotations in the canonical system of the Holy Bible:

OT:

Historical Books: -

Wisdom Books: Ps 1:2; Ps 119[118]:11;

Prophetic Books: -

NT:

Narrative Scriptures (Mt, Mk, Lk, J, Acts): Lk 1:35; Lk 1:38; Lk 2:51; J 1:1; J 1:3; J 1:18; J 5:38; J 8:16; J 8:58; J 10:30;

Corpus Paulinum: Eph 3:17; Eph 4:29; Col 3:16; 2Tm 2:5;

Catholic Epistles: Jam 1:22; 2P 1:16-18;

Apocalypse: - 
The commentary on the second article of the Apostolic Symbol focuses on the Christological issues (Non solum est necesse Christianis unum Deum credere, et hunc esse creatorem caeli et terrae et omnium; sed etiam necesse est ut credant quod Deus est pater, et quod Christus sit verus filius Dei). It features 18 quotations from the Bible, whereby as many as 16 of which come from the New Testament. Of course, such a selection of source material is related to the Christological theme contemplated by Aquinas. The Gospel of St. John is cited as many as 7 times here. We must remember that this particular Gospel is a work of the most developed descending Christology, that is to say, it emphasizes the divine origin of Jesus as the Word and the Son. This resulted in the fact that in the entire history of theology and the development of the Christological dogma, the fourth Gospel was preferred as the primary source of argumentation and discussion. Moreover, Aquinas worked very hard on the Gospel of John, which is reflected in the exegetic commentary entitled Lectura super Ioannum, written in the form of a reportatio drawn up by Reginald of Piperno, which is the result of lectures from the years 1270-1272. ${ }^{9}$ This commentary, apart from the lecture on the Epistle to Romans by St. Paul the Apostle (Super Epistolam B. Pauli ad Romanos lectura) is considered to be the pinnacle of the exegetical work of the Angelic Doctor.

In the currently analyzed passage of the sermon, the Fathers of the Church are invoked as many as three times. Aquinas does not, however, quote individual authors, but instead, he recalls the collective category of Fathers.

In the first case (2:28: et apostoli et sancti patres posuerunt inter articulos fidei quod Christus est filius Dei, dicentes: et in Iesum Christum filium eius, scilicet Dei) it is not clear whether the conjunctive et in the wording of apostoli et sancti patres means to distinguish the two separate categories of persons, i.e. "apostles" on the one hand and "holy fathers" on the other, or whether it has an explanatory function, i.e. "apostles, that is, the Holy Fathers". The first hypothesis is supported by the fact that the collective consciousness of medieval Christians held the Apostle's Creed as arranged by the apostles themselves. On the other hand, however, in 2:29, Aquinas uses the phrase "the Holy Fathers" again stating that et ideo sancti patres addiderunt in alio symbolo contra primum. He evokes here another confession of creed designed by the Holy Fathers, namely the Nicene-Constantinopolitan Creed. Perhaps, therefore, the wording apostoli et sancti patres indicates that for the Angelic Doctor, the Apostolic Symbol is the fruit of not only the work of the apostles themselves, but its final form

9 Research on Thomas's exegesis of the Gospel according to St. John is included in the monograph: M. Dauphinais, M. Levering (eds.), Reading John with St. Thomas Aquinas. The Polish translation of the commentary: Tomasz z Akwinu, Komentarz do Ewangelii Jana. 
is the work of later thinkers, collectively called fathers. It is significant that 2:28 features a quote from Symbolum Apostolorum (Et in Iesum Christum Filium eius) and not from the Nicene-Constantinopolitan Creed (Et in unum Dominum Iesum Christum, Filium Dei).

In the case of 2:29, as already mentioned above, Aquinas quotes the NiceneConstantinopolitan Creed (filium Dei unigenitum [...] et ex patre natum ante omnia saecula). The very same situation takes place at 2:30 (Deum de Deo, lumen de lumine). Hence, in these last two cases the phrase "Holy Fathers" undoubtedly applies to the Fathers of the First Council of Nicaea (325 AD). ${ }^{10}$

Recalling the authors of creeds as auctoritates is an intentional treatment for Aquinas. Both creeds, the Symbolum Apostolorum and the Nicene-Constantinopolitan Creed were well-known to the public of his sermons. In addition, the texts of the creeds were very important not only for academic theology, but also in terms the doctrine of the Church. Their concise form concealed the entire deposit of Revelation in a synthetic design. They were no mere ordinary prayers, but a peculiar expression of the faith and identity of the entire Church. ${ }^{11}$

\subsection{Article No. 3 (Qui conceptus est de spiritu sancto, natus ex Maria virgine)}

The following table presents quotations from the Holy Scriptures and from the writings of the Church Fathers in a lecture on the third article of Symbolum apostolorum:

\begin{tabular}{|l|l|}
\hline \multicolumn{1}{|c|}{ The Scripture } & \multicolumn{1}{c|}{ The Church Fathers } \\
\hline J $1: 14$ & Fathers $(3.39)$ \\
Ba $3: 38$ & Fathers $(3.40)$ \\
Isa $8: 1$ & Fathers $(3.41)$ \\
Mt $25: 41$ & Fathers (3.42) \\
J $6: 38$ & Fathers (3.43) \\
Lk $24: 39$ & Fathers $(3.44)$ \\
Mt $1: 20$ & \\
Lk $1: 35$ & \\
Gal $4: 4$ & \\
J $12: 27$ & \\
\hline
\end{tabular}

10 For more on the First Council of Nicaea, cf.: H. Pietras, Sobór Nicejski (325).

11 For more on the theological and social function of creed, cf.: Benedict XVI / Joseph Ratzinger, Formal Principles of Christianity, pp. 85-96, 148-178. 
Mt 26:38

Phil 2:7

J 8:40

J $1: 18$

Rom 5:2

J 3:16

2P $1: 4$

Mt 24:28

Phil 1:23

The distribution of quotations in the canonical system of the Holy Bible:

OT:

Historical Books: -

Wisdom Books: -

Prophetic Books: Isa 8:1; Ba 3:38;

NT:

Narrative Scriptures (Mt, Mk, Lk, J, Acts): Mt 1:20; Mt 24:28; Mt 25:41; Mt 26:38;

Lk 1:35; Lk 24:39, J 1:14; J 1:18; J 3:16; J 6:38; J 8:40; J 12:27;

Corpus Paulinum: Rom 5:2; Ga 4:4; Phil 1:23; Phil 2:7;

Catholic Epistles: 2P 1:4;

Apocalypse: -

Another article of the Apostolic Symbol deals with the incarnation of the Son of God. Aquinas quotes the Holy Scriptures 19 times, 17 of which citations are intertextual references to the NT, whereby texts taken from the OT appear only twice. And again, such a distribution of quotations has its cause in the Christological content of the commented fragment of Symbolum apostolorum. Among the NT scriptures, the Gospel according to St. John is quoted most often - as many as six times. Already in the first paragraph, Thomas Aquinas emphasizes the significance of John the Evangelist's theological reflection for the correct understanding of the Christological doctrine:

Non solum est necessarium credere Christiano filium Dei, ut os tensum est; sed etiam oportet credere incarnationem eius. Et ideo beatus Ioannes postquam dixerat multa subtilia et ardua, consequenter insinuat nobis eius incarnationem, cum dicit: et verbum caro factum est.

In one of the cases, there is not a complex intertextual relationship but merely a reference to Philippians 1:23 in a commentary on 3:50. The follow- 
ing table compares the fragment of the sermon of Aquinas and the Latin text of Philippians 1:23:

\begin{tabular}{|l|l|}
\hline $\begin{array}{c}\text { Collationes in Symbolum Apostolorum } \\
\mathbf{3 : 5 0}\end{array}$ & \multicolumn{1}{|c|}{$\begin{array}{c}\text { Philippians 1:23 } \\
\text { (Vulgata Clementina) }\end{array}$} \\
\hline $\begin{array}{l}\text { Unde cum Christus sit frater noster, } \\
\text { debemus desiderare esse cum eo et } \\
\begin{array}{l}\text { coniungi ei (...) et apostolus desiderium } \\
\text { habebat dissolviet esse cum } \text { Christo }\end{array}\end{array}$ & $\begin{array}{l}\text { Coarctor autem e duobus: } \underline{\text { desiderium }} \\
\text { habens dissolvi, et esse cum Christo, } \\
\text { multo magis melius }\end{array}$ \\
\hline
\end{tabular}

The first part of the aforementioned fragment of the Angelic Doctor's lecture, presenting our desire to connect with Christ, takes the form of a recontextualisation. This is how V.K. Robbins defines this phenomenon:

In contrast to recitation, recontextualization presents wording from biblical texts without explicit statement or implication that the words "stand written" anywhere else. This may occur either in narration or in attributed speech. ${ }^{12}$

At the same time, the second part of the analyzed passage of the sermon contains a classic quote from Philippians 1:23, which can be qualified as a replication of exact words with one or more differences. We must remember that the comments on the epistles forming part of the Corpus Paulinum belong to the very important exegetical and theological achievements of the Angelic Doctor. According to J.-P. Torrell, Aquinas worked on a lecture regarding the epistles of the Apostle of the Nations during his stay in Naples, in the years $1272-1723 .{ }^{13}$ In turn, T. Prügl suggests that these commentaries were written much earlier, in 1256, when Aquinas was a freshly minted magister in sacra pagina. ${ }^{14}$ If the hypothesis on the formation of collationes to the Apostles' Creed during the Lent of 1273, as well as the first hypothesis of dating the lecture on Corpus Paulinum proved to be true, then we would have to be dealing with works created in a very short span of time.

In paragraphs 3:39-3:44, Aquinas once again recalls the Fathers of the First Council of Nicaea (325 AD) and the text of the Nicene-Constantinopolitan

12 V.K. Robbins, Exploring the Texture of Texts, p. 48.

13 J.-P. Torrell, Thomas Aquinas, pp. 294-302.

14 T. Prügl, Thomas Aquinas as Interpreter of Scripture, pp. 386-415; see also: R. Wielockx, Au sujet du commentaire de Saint Thomas sur le "Corpus Paulinum", pp. 150-177. 
Creed. The manner of quoting subsequent fragments of the Mass confession of faith is analogous to the commentary on the third article.

\section{Conclusion}

This article presents an inventory of quotations from the Holy Scriptures and from the works by the Fathers of the Church featured in the Prooemium and in the sermon of Thomas Aquinas pertaining to the first three articles of Symbolum Apostolorum. The research conducted above is preliminary and contributes to a more thorough analysis of the place and role of quotations in the sermons of Aquinas. This preliminary outline, however, allows for an indication of some suggestions and research directions. First of all, it seems that the Angelic Doctor tries to quote the fragments of the Bible in a literal form or in a nearly verbatim form (in the light of the terminology coined by V.K. Robbins: a replication of exact words of another written text or a replication of exact words with one or more differences). The final conclusion, however, would require a detailed textual criticism of all quotations throughout the entire sermon on the Apostles' Creed. What would be also interesting is to follow in detail the hermeneutic process of St. Thomas, in other words, to identify the process of selecting quotations for specific parts of the sermon. The use of the Vulgate version by Aquinas is a separate topic. Secondly, references to the Holy Fathers are less numerous and they are not always literal quotations. It happens that St. Thomas only refers to certain views and thoughts of Fathers like St. Augustine or St. Gregory the Great. In addition, there is also a collective category of the Fathers, in those loci where specific fragments of the Apostles' Creed or Nicene-Constantinopolitan Creed are quoted.

\section{Bibliography}

Benedykt XVI/Ratzinger J., Formalne zasady chrześcijaństwa. Szkice do teologii fundamentalnej, trans. W. Szymona, Poznań 2009.

Chenu M.-D., Wstęp do filozofii św. Tomasza z Akwinu, trans. H. Rosnerowa, Kęty 2001.

Dauphinais M., Levering M. (eds.), Reading John with St. Thomas Aquinas. Theological Exegesis and Speculative Theology, Washington 2000.

Kowalski M., "Retorka i socjoretoryka w lekturze tekstów Nowego Testamentu. Cz. 2: Socjoretoryka - projekt holistycznej lektury tekstu," BibAn 7(2017), pp. 107$-147$.

Levering M., Dauphinais. D (eds.), Reading Romans with St. Thomas Aquinas, Washington 2012. 
Levering M., Pismo Święte i metafizyka. Tomasz z Akwinu i odnowa teologii trynitarnej, trans. M. Romanek, Kraków 2016.

Mandonnet P., "Le Carême de saint Thomas d’Aquin à Naples (1273)," in: Miscellanea storico-artistica, Roma 1924, pp. 195-212.

Pietras H., Sobór Nicejski (325). Kontekst religijny i polityczny, dokumenty, komentarze, Kraków 2013.

Prügl T., “Thomas Aquinas as Interpreter of Scripture," in: R. van Nieuwenhove, J. Wawrykow (eds.), The Theology of Thomas Aquinas, Notre Dame: 2005, pp. 386-415.

Robbins V.K., Exploring the Texture of Texts: A Guide to Socio-Rethorical Interpretation, Valley Forge 1996.

Robbins V.K., Tapestry of Early Christian Discourse. Rhetoric, Society, and Ideology, London 1996.

Robbins V.K., The Invention of Christian Discourse, Blandford 2009.

Roszak P., "The place and function of biblical citation in Thomas Aquinas' exegesis," in: Roszak P., Vijgen J. (eds.), Reading Sacred Scripture with Thomas Aquinas. Hermeneutical Tools, Theological Questions and New Perspectives, Turnhout 2015, pp. 115-139.

Roszak P., Vijgen J. (eds.), Reading Sacred Scripture with Thomas Aquinas. Hermeneutical Tools, Theological Questions and New Perspectives, Turnhout 2015.

Roszak P., Vijgen J. (eds.), Towards a Biblical Thomism. Thomas Aquinas and the Renewal of Biblical Theology, Pamplona 2018.

Tomasz z Akwinu, Expositio in Symbolum Apostolorum. Reportatio Reginaldi de Piperno, http://www.corpusthomisticum.org/csv.html [access: 04.04.2019].

Tomasz z Akwinu, Komentarz do Ewangelii Jana, trans. T Bartoś, Kęty 2018.

Tomasz z Akwinu, Wykład Pacierza, Poznań 2019.

Torrel J.-P., Tomasz z Akwinu - człowiek i dzieło, trans. A. Kuryś, Kęty-Warszawa 2008.

Valkenberg W.G.B.M., Words of the living God. Place and Function of Holy Scripture in the Theology of St. Thomas Aquinas, Leuven 2000.

Wielockx R., "Au sujet du commentaire de Saint Thomas sur le Corpus Paulinum. Critique littéraire," in : Doctor Communis. L'interpretazione di San Tommaso delle dottrine di San Paolo, Vatican City 2009, pp. 150-177. 